\title{
Predicting bending creep of laminated veneer lumber (LVL) sengon (Paraserianthes falcataria) beams from initial creep test data
}

\author{
Achmad Basuki ${ }^{1,}$, Ali Awaludin ${ }^{2}$, Bambang Suhendro ${ }^{2}$, and Suprapto Siswosukarto ${ }^{2}$ \\ ${ }^{1}$ Departement of Civil Engineering, Universitas Sebelas Maret, Surakarta 57126, Indonesia, and \\ Ph.D. Student Departement of Civil Engineering and Environment, Universitas Gadjah Mada, \\ Yogyakata 55284, Indonesia. \\ ${ }^{2}$ Departement of Civil Engineering and Environment, Universitas Gadjah Mada, Yogyakata 55284, \\ Indonesia.
}

\begin{abstract}
This paper presents the results of creep tests of Laminated Veneer Lumber Sengon (LVL Sengon) beams, aiming to determine the creep factor and to establish the prediction beam deflection based on the initial creep test data. The LVL Sengon beams have a cross section of 40 $\mathrm{mm}$ by $80 \mathrm{~mm}$ and a clear span length of $2,000 \mathrm{~mm}$, they were loaded at midspan for three different stress levels: $30 \%, 40 \%$, and $50 \%$ of the ultimate load within 30, 60, and 90 days. Each loading level consists of four repetitive beams where one beam was wrapped with a plastic sheet. The test results showed that for 90 days the bending creep test can not determine the secondary creep yet. Curve fitting of bending creep test data indicated that the parameters of the Modified Burger creep model of the first 30 days can be accurately used to predict the beam deflection curve up to 60 and 90 days of loading.
\end{abstract}

\section{Introduction}

Creep is one factor that must be considered in the design of a building structure. Creep is a deflection or deformation of structures due to permanent loading over time. Creep can cause serviceability problems due to excessive deformation or to a reduction in strength [1]. The total deformation during the service life of a building must be limited. Therefore, understanding creep behaviour of material and structure will allow one to predict the behaviour of a building during its service life [2,3], including buildings using wood and wood based (wood engineered) materials [4].

Sengon (Paraserianthes falcataria) laminated veneer lumber (LVL Sengon) is an engineered wood material that is recently developed as a structural component in Indonesia and is manufactured by laminating veneers obtained from Sengon timber [5]. Sengon is a fast- growing timber that can replace solid wood. Each veneer has a thickness from 2.5 to

\footnotetext{
* Corresponding author: achmad.basuki@mail.ugm.ac.id
} 
$3.2 \mathrm{~mm}$ and plies parallel to length using melamine urea formaldehyde (UF) adhesive under 0.6-0.7 MPa pressure.

Similar with other wood structural materials, the utilization of LVL Sengon needs engineering properties and mechanical tests in the short-term or long-term. Compared to solid Sengon, LVL Sengon has some improvements on engineering properties, as shown in Table 1.

Table 1. Engineering properties of solid sengon and LVL sengon [6].

\begin{tabular}{|c|c|c|}
\hline $\begin{array}{c}\text { Engineering } \\
\text { properties }\end{array}$ & Solid Sengon & LVL Sengon \\
\hline Density & 0.26 & 0.41 \\
\hline MOE $(\mathrm{MPa})$ & $1250-3300$ & $5700-9000$ \\
\hline MOR $(\mathrm{MPa})$ & 26.61 & 38.78 \\
\hline Tension // $(\mathrm{MPa})$ & 20.00 & 46.69 \\
\hline Compression // $(\mathrm{MPa})$ & 13.29 & 22.82 \\
\hline Compression $\perp(\mathrm{MPa})$ & 3.52 & 5.40 \\
\hline Shear $(\mathrm{MPa})$ & 0.60 & - \\
\hline
\end{tabular}

This study aims to examine the bending creep of LVL Sengon through rheological (mechanical) and phenomenological models. The rheological model is based on a mathematical function to best fit experimental bending creep data, and the phenomenological model is based on constants obtained from experimental bending creep data that represents spring and dashpot model. Prediction of long term creep of LVL Sengon is calculated based on short term experiment bending creep data.

Hunt stated that the result of creep experiments is generally divided into two parts: a primary or short-term part and a secondary or long-term part. A plot of creep result against the logarithmic of time showed that after primary creep occurred in one or two days, it follows a straight line represented as secondary creep [6]. However, there is a lack of information about the long-term behaviour of material or structure components under a constant loading.

\section{Bending creep experiment}

Creep experiments has been done on LVL Sengon beams for 3 (three) months in a temperature- and humidity- controlled room. The dimensions of LVL Sengon beam is 40 $\mathrm{mm}$ in thickness, $80 \mathrm{~mm}$ in width, and $2000 \mathrm{~mm}$ in (clear) length. Beam edges are simply supported and loaded at mid-span by loading levels of $30 \%, 40 \%$, and $50 \%$ of the ultimate load, which correspond to $215 \mathrm{~N}, 285 \mathrm{~N}$ and $355 \mathrm{~N}$, respectively.

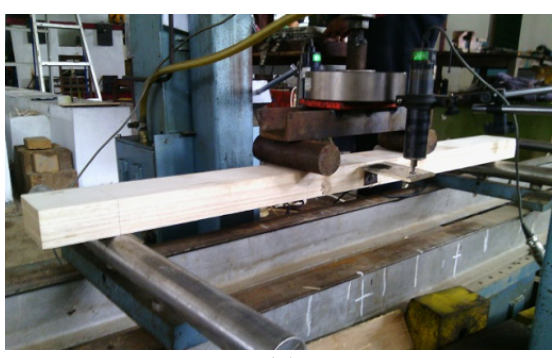

(a)

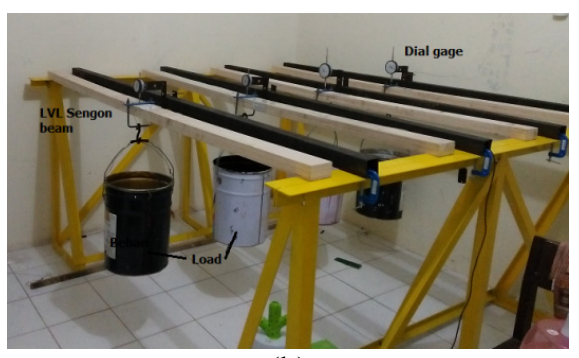

(b)

Fig. 1. (a) Bending edgewise test, (b) Setting of bending creep test of LVL Sengon. 
The ultimate load was taken from the bending test of LVL Sengon based on the Japan Agriculture Standard for Laminated Veneer Lumber (LVL) Notification No.2773, 2013, see Fig. 1.

The room for bending creep test was controlled at a constant temperature of $27^{\circ} \mathrm{C}$ by means of an Air Conditioner (AC) and at a minimal $65 \%$ in relative humidity (RH) by means of a humidifier. However, actual measurement inside the room showed a temperature range of $24.9^{\circ} \mathrm{C}-26.3^{\circ} \mathrm{C}$ and $\mathrm{RH}$ of $65 \%-99 \%$, as shown in Fig. 2. There are three unwrapped beams and one wrapped (with plastic sheet) beam for each loading level.

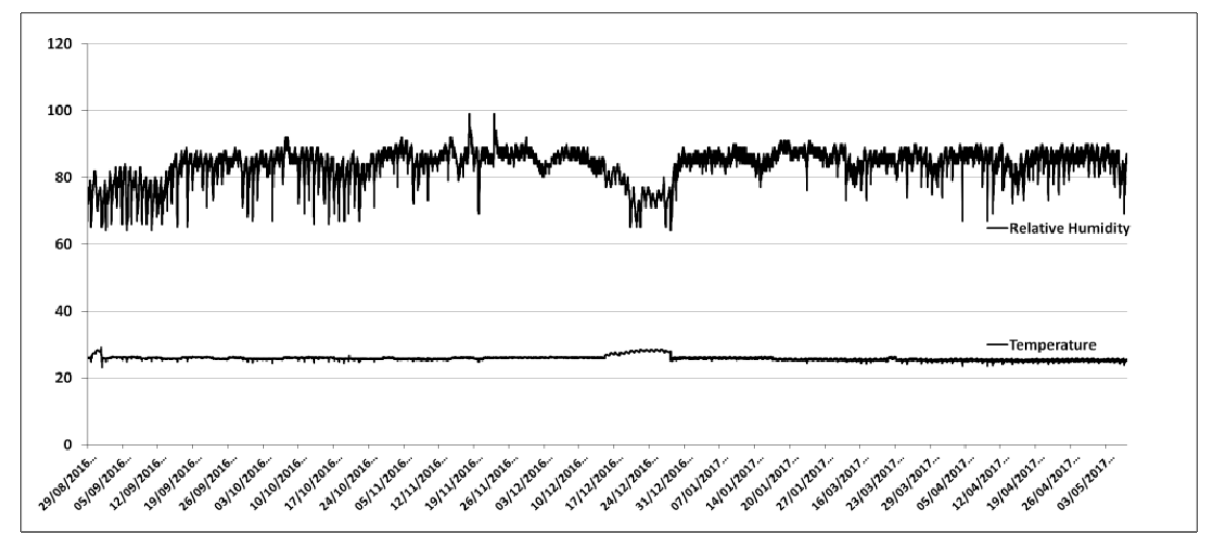

Fig. 2. Temperature and relative humidity data over bending creep test.

\subsection{Creep model of LVL sengon}

LVL Sengon is assumed to be a viscoelastic material. A viscoelastic material exhibits elasticity under rapid loading, then its strain increases slowly and continuously. Viscoelasticity combines elasticity and viscosity (viscous flow) [7]. Elastic materials can be represented by a Hookean spring and the force-deformation response is independent of time, while the dashpot represents viscous materials and can describe time-dependent behaviour. The creep model of viscoelastic materials can be arranged in spring and dashpot in various combinations [8].

The Maxwell creep model combines a spring and a dashpot joined in series and the Kelvin creep model consists of a spring and a dashpot in parallel arrangement. The Burger or four-element creep model [7] is represented by inserting the Kelvin creep model between a spring and a dashpot of the Maxwell creep model, as shown in Fig. 3. The mathematical form of the Burger model is given in Eq. (1).

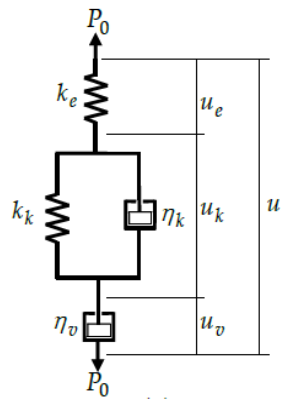

Fig. 3. Burger creep model. 


$$
u(t)=\beta_{1}+\beta_{2}\left(1-e^{-\left(\beta_{3}\right) t}\right)+\beta_{4} t
$$

where $\beta_{1}=P_{0} / k_{e}, \beta_{2}=P_{0} / k_{k}, \beta_{3}=k_{k} / \eta_{k}$, and $\beta_{4}=P_{0} / \eta_{v}$.

Initial elastic deformation is denoted by $\beta_{1}$ that is associated with the spring constant $k_{e} . \beta_{2}$ and $\beta_{3}$ correspond to the delayed elastic or recoverable creep components and are associated with the combined effect of the spring constant $k_{k}$ and the dashpot constant $\eta_{k}$, and finally $\beta_{4}$ represents the irrecoverable creep component contributed by the dashpot constant $\eta_{v}$.

In other words, Eq. (1) shows that the first term of the right-hand side represents the instantaneous deformation, the second term describes the delayed elasticity, and the third term describes the plastic flow component. [9]

\subsection{Modification of burger creep model}

Dinwoodie $[8,10]$ states that any further models of creep tests are demanded to be able to predict long-term performance from short-term data. For timber and the various board materials, the third term in the right-hand side of the Burger creep model needs to be modified to a non-linear form by powering the variable $\mathrm{t}$ with the viscous modification factor $\beta_{5}$. So, Eq. (1) yields to become Eq. (2).

$$
u(t)=\beta_{1}+\beta_{2}\left(1-e^{-\left(\beta_{3}\right) t}\right)+\beta_{4} t^{\beta_{5}}
$$

Value of $\beta_{5}$ is $0<\mathrm{x}<1$.

\section{Result and discussion}

Bending creep test of LVL Sengon beams have been conducted for three months at each stress level. The temperature and relative humidity $(\mathrm{RH})$ of the room test were continuously monitored, and deflection of the beams at mid span was recorded. The wrapped LVL Sengon beam in each load level of bending creep test was expected to exhibit the influence of change in water content in rate of creep.

The creep deflection data of LVL Sengon beams for each load level are plotted and can be seen in Fig. 4.

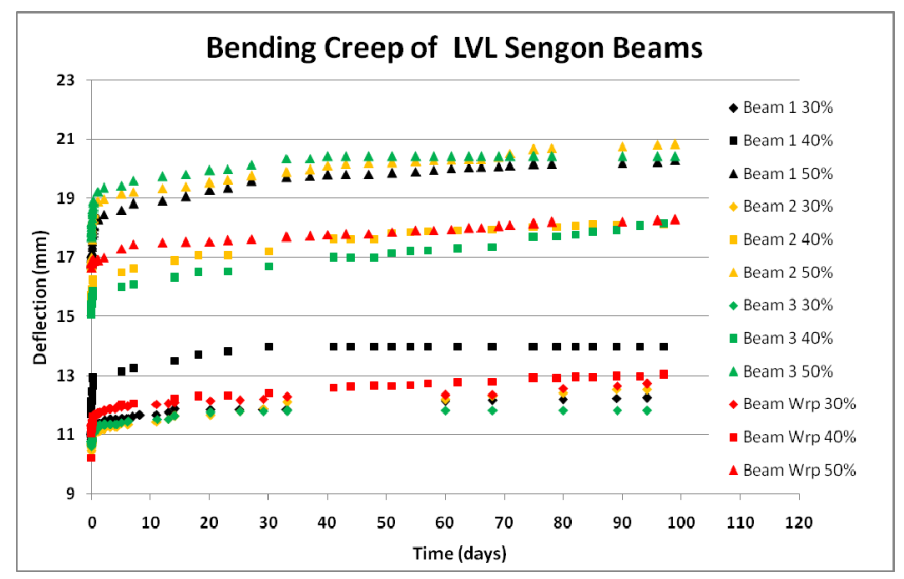

Fig. 4. Plotting of bending creep LVL sengon test 
Fig. 3 showed that the primary creep occurred in the first 30.5-56 days of the bending creep test. At each stress level, the bending creep of LVL Sengon has the same pattern, which in secondary creep, the creep data tends to be linear or has a constant creep rate.

By using the Toolbox Solver program available in Microsoft Excel, the parameters in Eq. (1) and (2) that represent the Burger and Modified Burger creep model are determined, and plotted to bending creep data, as be shown in Fig. 5, 6 and 7, and the correlation coefficient ( $\mathrm{r}$ square, $r^{2}$ ) can be calculated. Table 2, Table 3, and Table 4 show the parameters and the correlation coefficient of the curve fitting the Burger and Modified Burger models for load levels of $30 \%, 40 \%$, and $50 \%$, respectively. The modified Burger model has a correlation coefficient value above 0.9 . However, the primary or secondary creep cannot be determined yet because for 90 days the bending creep test deflection of beam still tend to rise and asymptote was not yet reached.

Table 2. Parameters and correlation coefficient of bending creep test - load level $30 \%$.

\begin{tabular}{|c|c|c|c|c|c|c|c|c|}
\hline $\begin{array}{c}\text { Load } \\
\text { Level } \\
\mathbf{3 0 \%}\end{array}$ & \multicolumn{2}{|c|}{ Beam 1 } & \multicolumn{2}{c|}{ Beam 2 } & \multicolumn{2}{c|}{ Beam 3 } & \multicolumn{2}{c|}{ Wrapped Beam } \\
\cline { 2 - 9 } & Burger & $\begin{array}{c}\text { Modified } \\
\text { Burger }\end{array}$ & Burger & $\begin{array}{c}\text { Modified } \\
\text { Burger }\end{array}$ & Burger & $\begin{array}{c}\text { Modified } \\
\text { Burger }\end{array}$ & Burger & $\begin{array}{c}\text { Modified } \\
\text { Burger }\end{array}$ \\
\hline $\boldsymbol{\beta} 1$ & 11.014462 & 10.743241 & 10.630519 & 10.045564 & 10.755228 & 9.8913208 & 11.275741 & 11.112222 \\
\hline $\boldsymbol{\beta 2}$ & 0.4596346 & 0.1059182 & 0.5918641 & 7.1551585 & 0.6417043 & 0.1212905 & 0.557184 & 0.1632276 \\
\hline $\boldsymbol{\beta 3}$ & 1.5091411 & 326.13852 & 3.9302119 & 0.0012219 & 2.1939024 & 0.1449747 & 2.9283197 & 6.87342 \\
\hline $\boldsymbol{\beta 4}$ & 0.0152939 & 0.5014498 & 0.0157328 & 1.0624344 & 0.0060496 & 1.3068948 & 0.0105215 & 0.4635783 \\
\hline $\boldsymbol{\beta 5}$ & & 0.217885 & & 0.1097768 & & 0.0798948 & & 0.2106864 \\
\hline $\mathbf{r}^{\wedge} \mathbf{2}$ & $\mathbf{0 . 7 6 1 3 9 9 6}$ & $\mathbf{0 . 9 9 1 8 1 7 1}$ & $\mathbf{0 . 9 5 9 5 3 3 6}$ & $\mathbf{0 . 9 9 1 3 0 9 1}$ & $\mathbf{0 . 9 6 0 2 5 7 9}$ & $\mathbf{0 . 9 8 7 9 4 8 8}$ & $\mathbf{0 . 9 6 6 6 5 3 8}$ & $\mathbf{0 . 9 8 5 1 3 3 5}$ \\
\hline
\end{tabular}

Table 3. Parameters and correlation coefficient of bending creep test - $40 \%$ load level

\begin{tabular}{|c|c|c|c|c|c|c|c|c|}
\hline $\begin{array}{c}\text { Load } \\
\text { Level } \\
\mathbf{4 0 \%}\end{array}$ & \multicolumn{2}{|c|}{ Beam 1 } & \multicolumn{2}{c|}{ Beam 2 } & \multicolumn{2}{c|}{ Beam 3 } & \multicolumn{2}{c|}{ Wrapped Beam } \\
\cline { 2 - 9 } & Burger & $\begin{array}{c}\text { Modified } \\
\text { Burger }\end{array}$ & Burger & $\begin{array}{c}\text { Modified } \\
\text { Burger }\end{array}$ & Burger & $\begin{array}{c}\text { Modified } \\
\text { Burger }\end{array}$ & Burger & $\begin{array}{c}\text { Modified } \\
\text { Burger }\end{array}$ \\
\hline $\boldsymbol{\beta 1}$ & 11.963632 & 11.665513 & 15.579611 & 15.083565 & 15.257304 & 15.195111 & 11.044243 & 10.417463 \\
\hline $\boldsymbol{\beta 2}$ & 1.5549819 & 0.6343554 & 1.1255464 & 1.0117962 & 0.709855 & 0.5395663 & 1.0175549 & 0.1 \\
\hline $\boldsymbol{\beta 3}$ & 3.0377474 & 4.9188426 & 2.9299405 & 0.0185637 & 5.9720318 & 19.664109 & 3.0567505 & 2.4553115 \\
\hline $\boldsymbol{\beta} \mathbf{4}$ & 0.0065362 & 0.7927475 & 0.0171349 & 1.1316776 & 0.0222004 & 0.0680656 & 0.0107038 & 1.2869235 \\
\hline $\boldsymbol{\beta 5}$ & & 0.1802985 & & 0.1469388 & & 0.7713479 & & 0.1336519 \\
\hline $\mathbf{r}^{\wedge} \mathbf{2}$ & $\mathbf{0 . 9 7 6 5 1 9 1}$ & $\mathbf{0 . 9 8 9 8 1 6 1}$ & $\mathbf{0 . 9 7 6 5 1 9 1}$ & $\mathbf{0 . 9 9 4 4 0 4}$ & $\mathbf{0 . 9 9 4 7 8 7 3}$ & $\mathbf{0 . 9 9 6 0 1 7 7}$ & $\mathbf{0 . 9 6 8 2 6 7 9}$ & $\mathbf{0 . 9 8 8 8 3 6 5}$ \\
\hline
\end{tabular}

Table 4. Parameters and correlation coefficient of bending creep test - $50 \%$ load level

\begin{tabular}{|c|c|c|c|c|c|c|c|c|}
\hline $\begin{array}{c}\text { Load } \\
\text { Level } \\
\mathbf{5 0 \%}\end{array}$ & \multicolumn{2}{|c|}{ Beam 1 } & \multicolumn{2}{c|}{ Beam 2 } & \multicolumn{2}{c|}{ Beam 3 } & \multicolumn{2}{c|}{ Wrapped Beam } \\
\cline { 2 - 9 } & Burger & $\begin{array}{c}\text { Modified } \\
\text { Burger }\end{array}$ & Burger & $\begin{array}{c}\text { Modified } \\
\text { Burger }\end{array}$ & Burger & $\begin{array}{c}\text { Modified } \\
\text { Burger }\end{array}$ & Burger & $\begin{array}{c}\text { Modified } \\
\text { Burger }\end{array}$ \\
\hline $\boldsymbol{\beta} 1$ & 16.929935 & 16.600675 & 16.717006 & 16.555549 & 17.979456 & 16.470662 & 16.823075 & 16.815437 \\
\hline $\boldsymbol{\beta 2}$ & 1.6432949 & 0.6772799 & 2.2854176 & 1.8998207 & 1.8091653 & 0.2722463 & 0.5707824 & 0.3599286 \\
\hline $\boldsymbol{\beta 3}$ & 4.8883584 & 18.898913 & 11.168978 & 23.369226 & 2.7157508 & 28.777776 & 0.2670009 & 0.4405904 \\
\hline $\boldsymbol{\beta 4}$ & 0.0270193 & 0.9640834 & 0.020849 & 0.2313281 & 0.0076878 & 2.4088906 & 0.0089837 & 0.0528588 \\
\hline $\boldsymbol{\beta 5}$ & & 0.2500661 & & 0.5183995 & & 0.0986125 & & 0.6584842 \\
\hline $\mathbf{r}^{\wedge} \mathbf{2}$ & $\mathbf{0 . 8 8 7 7 8 1}$ & $\mathbf{0 . 9 9 7 7 2 8 7}$ & $\mathbf{0 . 9 8 2 3 2 8 5}$ & $\mathbf{0 . 9 9 4 2 4 9 5}$ & $\mathbf{0 . 9 5 8 8 1 5 7}$ & $\mathbf{0 . 9 9 1 5 6 1 6}$ & $\mathbf{0 . 9 9 3 9 3 5 6}$ & $\mathbf{0 . 9 9 4 5 3 0 1}$ \\
\hline
\end{tabular}



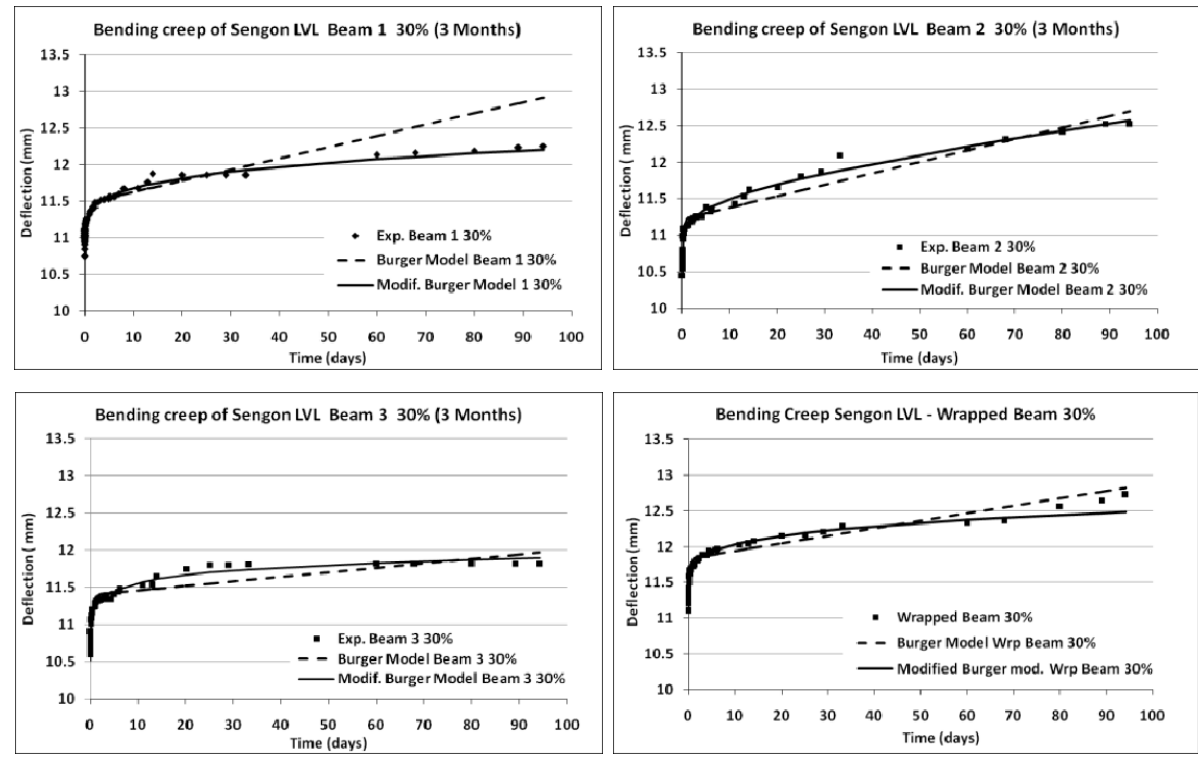

Fig. 5. Curve fitting of bending creep data - load level $30 \%$.
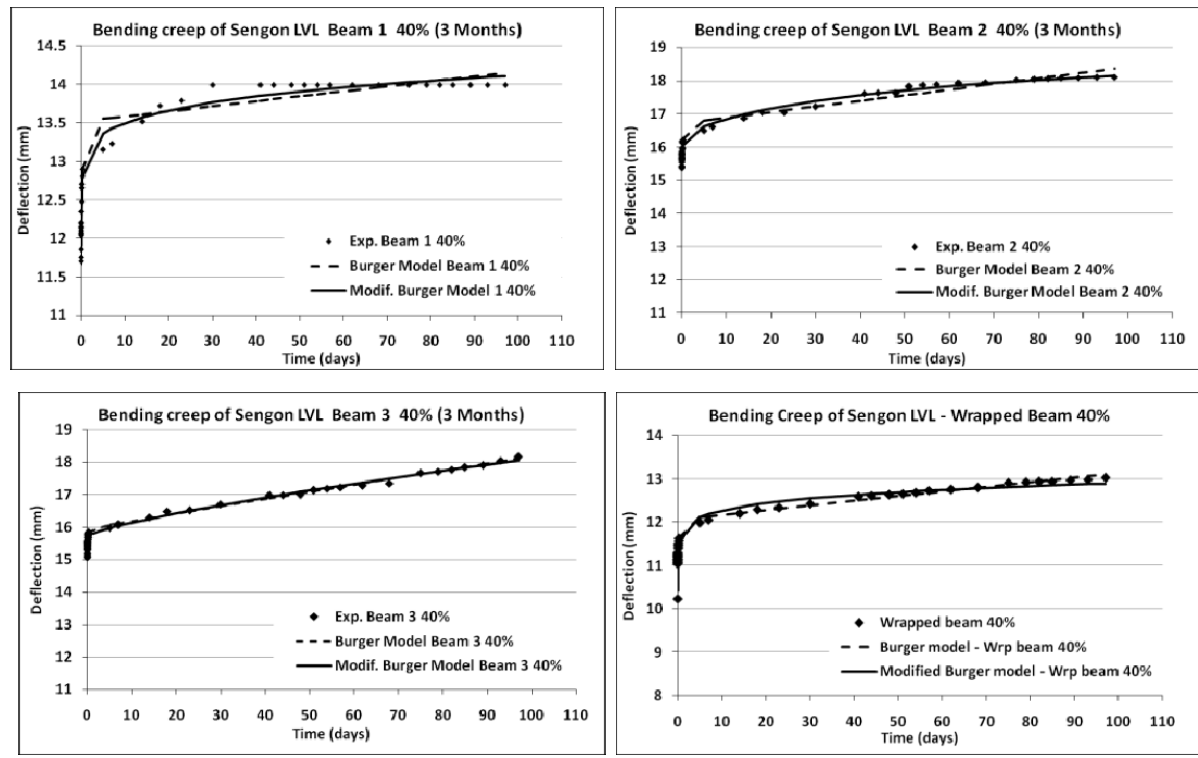

Fig. 6. Curve fitting of bending creep data - load level $40 \%$. 

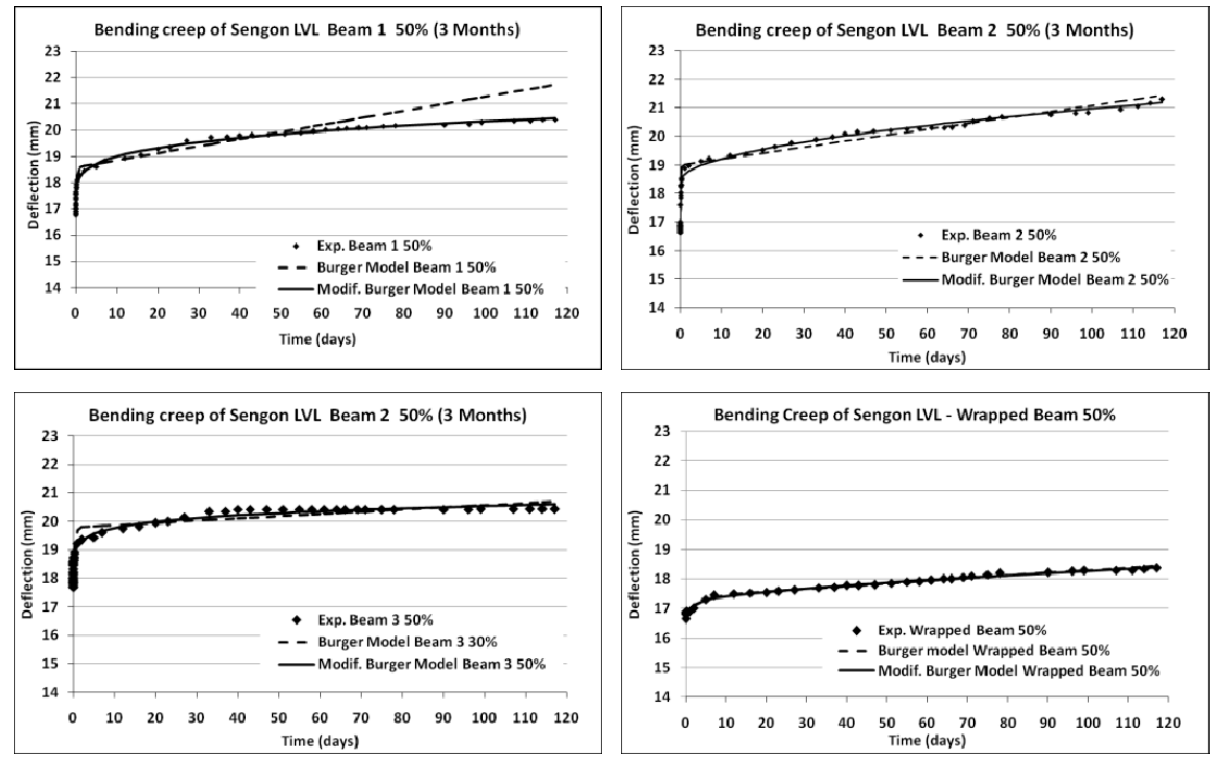

Fig. 7. Curve fitting of bending creep data - load level 50\%.

Based on the result of the bending creep test of LVL Sengon beam, bending creep modelling by the Modified Burger model fit enough to creep test data. So, its model can predict the continuous creep. Table 2 shows the correlation coefficient of fitting the curve data for each beam and load level.

Table 2. The correlation coefficient $\left(\mathrm{R}^{2}\right)$ of fitting 1-month creep data, prediction 2 and 3 months based on fitting 1-month creep data.

\begin{tabular}{|c|c|c|c|c|c|c|c|}
\hline \multirow[b]{2}{*}{ Specimen } & \multirow[b]{2}{*}{$\begin{array}{l}\text { Load } \\
\text { Level }\end{array}$} & \multicolumn{2}{|c|}{1 Month } & \multicolumn{2}{|c|}{$\begin{array}{l}\text { Prediction } 2 \\
\text { months }\end{array}$} & \multicolumn{2}{|c|}{ Prediction 3 months } \\
\hline & & $\begin{array}{c}\text { Burger } \\
\text { model }\end{array}$ & $\begin{array}{l}\text { Modified } \\
\text { Burger } \\
\text { model }\end{array}$ & $\begin{array}{c}\text { Burger } \\
\text { model }\end{array}$ & $\begin{array}{c}\text { Modified } \\
\text { Burger } \\
\text { model }\end{array}$ & $\begin{array}{c}\text { Burger } \\
\text { model }\end{array}$ & $\begin{array}{c}\text { Modified } \\
\text { Burger } \\
\text { model }\end{array}$ \\
\hline \multirow{3}{*}{ Beam 1} & $30 \%$ & 0.9485 & 0.9933 & 0.9196 & 0.9932 & 0.6746 & 0.9945 \\
\hline & $40 \%$ & 0.9838 & 0.9678 & 0.8050 & 0.9760 & 0.0037 & 0.9446 \\
\hline & $50 \%$ & 0.9770 & 0.9904 & 0.7282 & 0.9738 & -0.8014 & 0.1857 \\
\hline \multirow{3}{*}{ Beam 2} & $30 \%$ & 0.9854 & 0.9541 & 0.9478 & 0.9584 & 0.7267 & 0.9626 \\
\hline & $40 \%$ & 0.9963 & 0.9967 & 0.9870 & 0.9658 & 0.8592 & 0.9572 \\
\hline & $50 \%$ & 0.9774 & 0.9020 & 0.9350 & 0.9463 & 0.5010 & 0.9668 \\
\hline \multirow{3}{*}{ Beam 3} & $30 \%$ & 0.9878 & 0.9888 & 0.9100 & 0.9409 & 0.2439 & 0.5452 \\
\hline & $40 \%$ & 0.9774 & 0.9804 & 0.9495 & 0.9897 & 0.8570 & 0.9923 \\
\hline & $50 \%$ & 0.9645 & 0.9807 & 0.8265 & 0.9860 & -1.1318 & 0.9868 \\
\hline \multirow{3}{*}{$\begin{array}{l}\text { Wrapped } \\
\text { Beam }\end{array}$} & $30 \%$ & 0.9735 & 0.9169 & 0.9310 & 0.9260 & 0.7579 & 0.9497 \\
\hline & $40 \%$ & 0.8862 & 0.9148 & 0.9313 & 0.9582 & 0.8612 & 0.9745 \\
\hline & $50 \%$ & 0.9775 & 0.9647 & 0.9581 & 0.9803 & 0.8369 & 0.9912 \\
\hline
\end{tabular}

This paper discusses the prediction of the bending creep of LVL Sengon beam from 1month data by using the Modified Burger model. Its coefficients or parameters will be used to predict 2- and 3-month bending creep. Results will be correlated with experiment bending creep data. Plotting bending creep data of beam 1, 2, 3, and the wrapped beam, as in Fig. 8, 9,10, and 11, respectively, showed that the Modified Burger model is good enough to predict 2- and 3-months bending creep from 1-month bending creep data. 

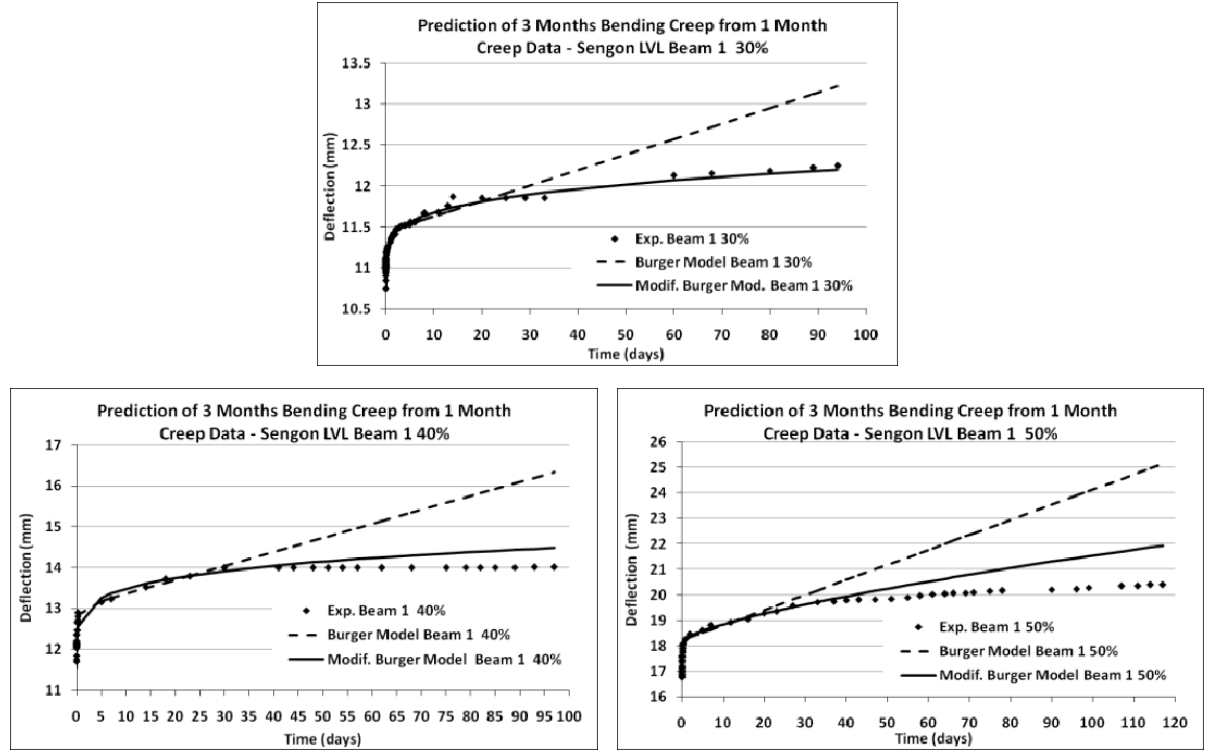

Fig. 8. Prediction 3 months of bending creep from 1-month creep data (Beam 1).
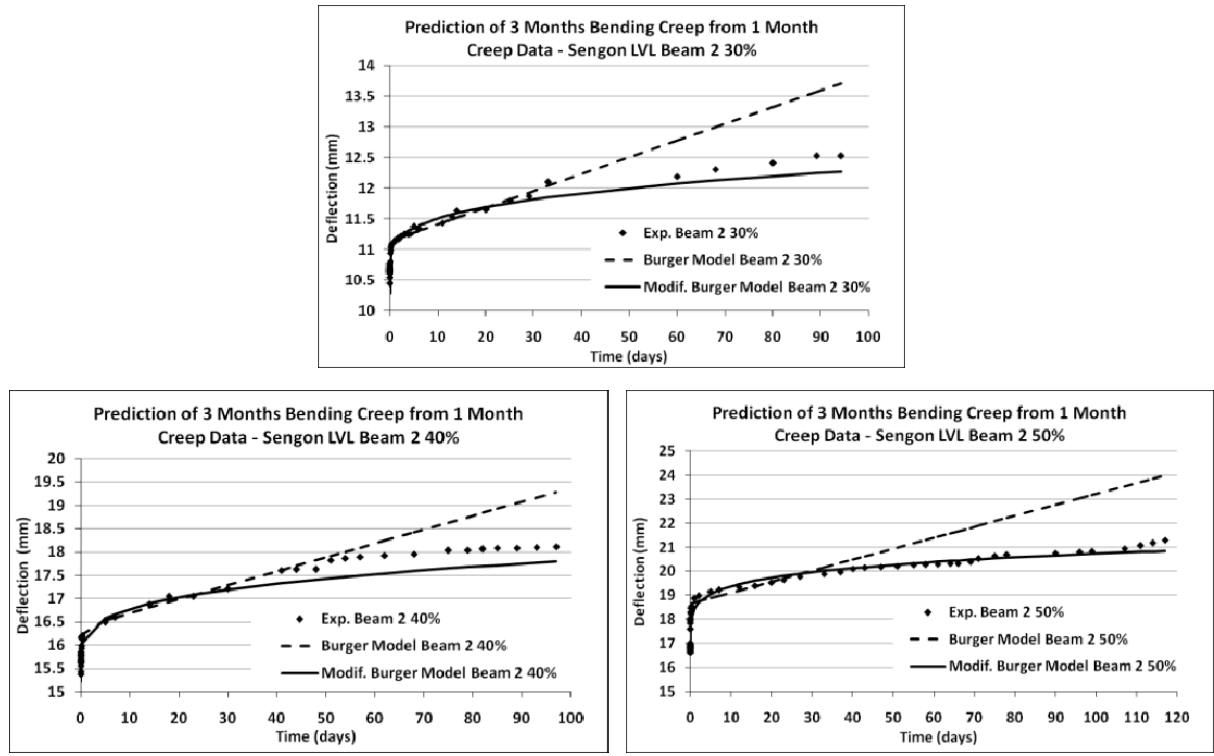

Fig. 9. Prediction 3 months of bending creep from 1-month creep data (Beam 2). 

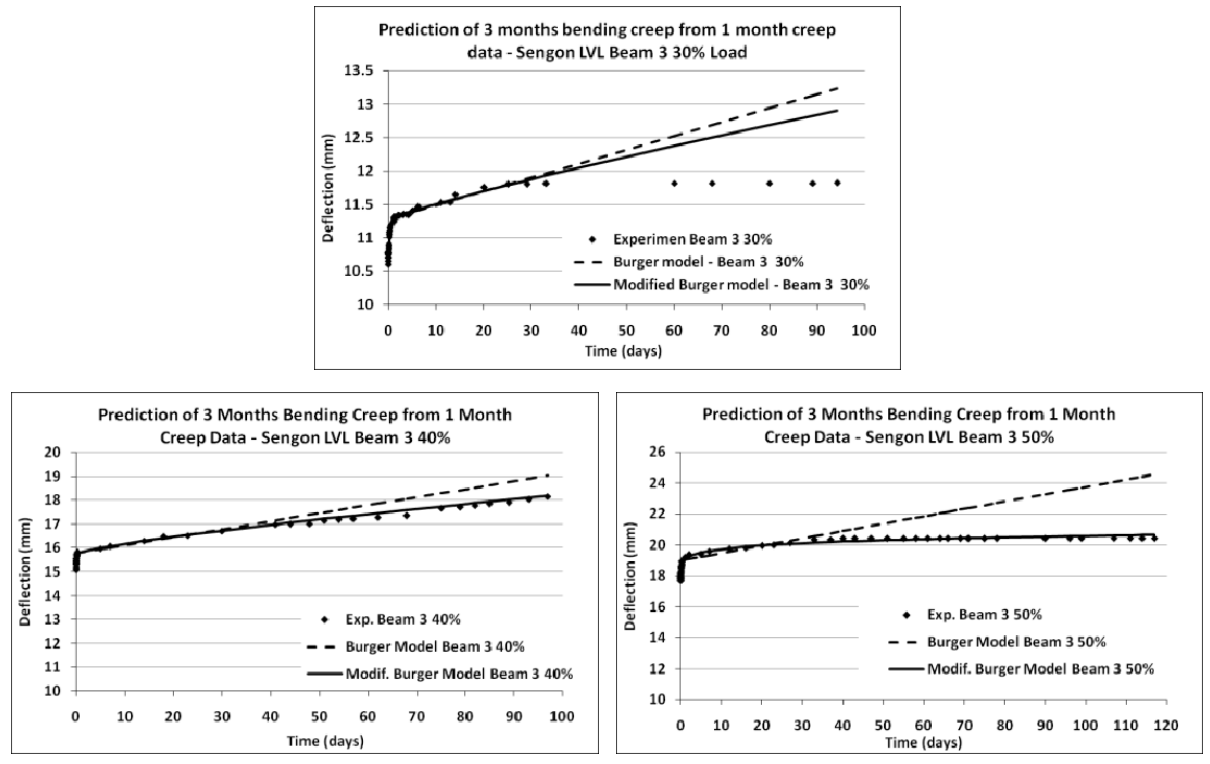

Fig. 10. Prediction 3 months of bending creep from 1-month creep data (Beam 3).
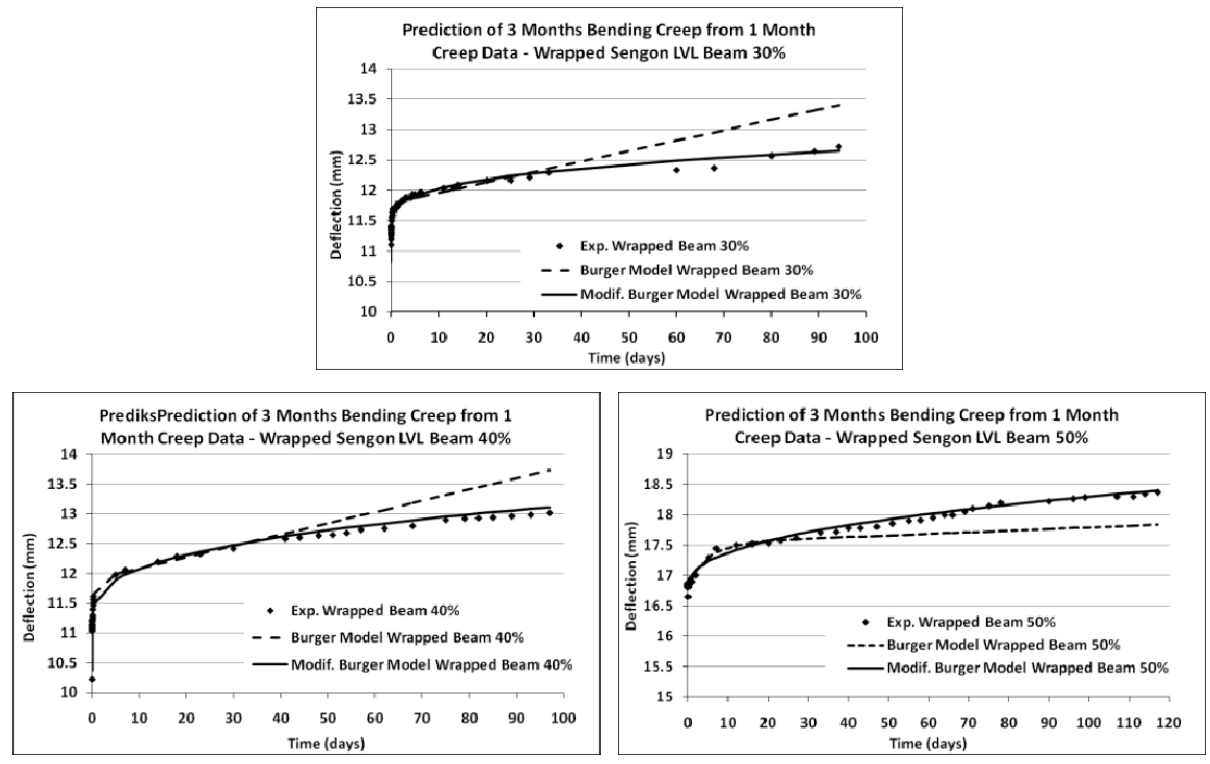

Fig. 11. Prediction 3 months of bending creep from 1-month creep data (Wrapped Beam).

\section{Conclusion}

This paper's study performed the prediction of three-months creep of LVL Sengon beam based on analysis of one-month bending creep data using the Burger and Modified Burger model. Curve fitting data showed that: 1. The Modified Burger model can be used to predict bending creep of LVL Sengon beam. 2. A longer bending creep testing is required to obtain a more satisfactory result on bending creep of LVL Sengon. 
The authors wish to thank PT. Sumber Graha Sejahtera - Tangerang for providing LVL Sengon used in this study.

\section{References}

1. J. Tissaoui, Effects of Long-Term Creep on The Integrity Modern Wood Structures, (VPISU, Virginia, 1996)

2. J. Bodig, and B.A. Jayne, Mechanics of Wood and Wood Composites, (KPC, Malabar Florida, 1982)

3. A. Awaludin, Ngudiyono, and A. Basuki, Civ. Eng. Dim. J. 18.2, 78-84 (2016)

4. Y. Shen and R. Gupta, Forest Product Journal, 47 (1), 89-96 (1997)

5. A. Awaludin, S. Shahidan, A. Basuki, S. S. M. Zuki, and F. M. Nazri, Int. J. Intg. Eng. 10.1, 17-22 (2018)

6. D. G. Hunt, Wood Sci. Technol. 38, 479-492 (2004)

7. W. N. Findley, J. S. Lai, and K. Onaran, Creep and Relaxation of Nonlinear Viscoelastic Materials, (DP, Inc. 1989)

8. Z. Cai, K. J. Fridley, M. O. Hunt, and D. V. Rosowsky, Wood and Fiber Science, 34(3), 425-433 (2002)

9. J. M. Dinwoodie, Timber: Its Nature and Behaviour, (E \& FN Spon, New York, 2004)

10. J. S. Mundy, P. W. Bonfield, J. M. Dinwoodie, and B. H. Paxton, Wood Science and Tehnology, 32, 261-272 (1998) 